\title{
A CORRELATIONAL STUDY BETWEEN STUDENTS' VOCABULARY MASTERY, READING HABIT AND WRITING SKILL
}

\author{
Rohmah Ayu Sulistyaningrum, Siswantoro, A. Handoko. P \\ English Education Department \\ Teacher Training and Education Faculty \\ Sebelas Maret University
}

Email: ayuurohmah@gmail.com

\begin{abstract}
The aims of the study are to determine the correlation between (1) vocabulary mastery and writing skill; (2) reading habit to writing skill; (3) vocabulary mastery, reading habit, and writing skill. The sample of the research is 26 second grade students in a junior high school in Karanganyar. In collecting the data, the researcher used questionnaire and test. The questionnaire was used to collect the data of students' reading habit, while the test was used to collect the data of vocabulary mastery and writing skill. In analyzing the data, the researcher used Simple Correlation and Multiple Correlation Technique. The result of this study show that (1) there is a positive correlation between vocabulary mastery and writing skill $\left(r_{X 1 Y}=0.74\right)$; (2) there is a positive correlation between reading habit and writing skill $\left(r_{X 2 Y}=0.63\right)$; $(3)$ there is a positive correlation between vocabulary mastery, reading habit, and writing skill $\left(r_{X 1 X 2 Y}=0.809\right)$.
\end{abstract}

Keywords: correlation study, vocabulary mastery, reading habit

\section{INTRODUCTION}

One of language skills that is important to be mastered by students is writing skill. It is important because gives many advantages to the students in learning the language and belongs to the most difficult skill in English. Good writing skill allows the students to communicate their message clearly and help them to study the other skill in English more effectively (Huy. 2015: 56). In addition, Patel and Jain (2008: 125) state, "writing is an essential feature of learning a language because it provides a very good means of foxing the vocabulary, spelling, and sentence pattern". With the explanations above it can be concluded that writing is an important skill which should be taught and give many advantages to the students in their study and their future life.
To reach a good ability in writing skill, they should learn with more struggles in writing, because it is the most difficult skill to be mastered by English foreign learners. They have difficulties in generating and organizing ideas and translating their ideas into readable text, Richard and Renandya (2002: 303). The same as Richard and Renandya, Barkaoui (2007: 35) argues that "writing is one of the most difficult skills that secondlanguage (L2) learners are expected to acquire, requiring the mastery of a variety of linguistic, cognitive, and sociocultural competencies". With the complex knowledge that should be acquired by the students, it makes writing to be a difficult skill to be mastered by second language learners. 
While the students learn to master writing skill, they have to pay attention to the aspects of writing skill such as language use, vocabulary, punctuation, and etcetera, to achieve the goal in academic purpose. All aspects of writing skill are important, but there is the most important aspect according to many experts that should be considered in learning writing. One of the most important aspects is vocabulary. It is because vocabulary is the core component of language skill. Without mastering vocabulary, we cannot express our ideas to communicate with the other person. In writing, vocabulary is very important. Vocabulary has an important role as an indicator when students do the assessment of writing. According to Solati-Dehkordi and Salehi (2016: 152) "vocabulary is one of the most an essential features of writing". Vocabulary can be used in writing assessment to find out the students' knowledge about the field. It is important in writing because it is one of the most an essential features and belongs to the criteria of good writing skill. Based on the descriptions above the writer assumes that one of the most important aspects to increase writing skill is vocabulary mastery.

Before writing, the students need the knowledge to transfer their ideas into readable text. Without the knowledge, they will get difficulties to transfer their ideas. Building knowledge can be gotten if the students have a good reading habit. Reading is one way to getting the information or knowledge. If we often read many kinds of text, we can gain the information from it. The information that we get can be used as a base or material to support our ideas in our writing. According to Krashen (2004: 37) "Reading is the only way we become a good reader, develop a good writing style, an adequate vocabulary, advanced grammatical competence, and the only way we become good spellers". By Krashen' statement, it can be inferred that reading can be used as a way to learn the aspect of writing skill such as mastering grammar, improve their vocabulary, and develop their writing skill. It can be assumed that reading habit has a positive effect in writing skill.

Based on the explanations above, the writer assumes that reading habit can affect the students' writing skill. Good reading habit can improve their writing skill. Good writing skill also can be affected by students' vocabulary mastery. Moreover, in this research, the writer discussed vocabulary mastery and reading habit. It is about the contribution of vocabulary mastery and reading habit to writing skill.

\section{LITERATURE REVIEW}

Writing is not a natural skill and belongs to productive skill because to create a well-written form, the writer has to consider the process and master the aspect of writing skill. Brown (2001: 335) states, "the products of writing skill are often the result of thinking, drafting, and revising procedures that require specialized skills, the skill that not every speaker develops naturally".

When people write something, they have purposes for writing. The purposes of writing have to do with the goals of writing. The purpose is to express or convey their ideas to the reader. According to Ur (2009: 163), the purpose of writing in principle is the expression of ideas, the conveying of a message to the reader; so the ideas themselves should arguably be seen as the most important aspect of the writing. Moreover, they have to consider 
who is the reader, because the purpose of writing is to communicate to a particular audience.

Based on the theories of writing above, it can be concluded that writing is a productive skill which involves the systematic process to express the ideas or to convey the messages to the reader in form of words into sentences, from sentences into coherent and cohesive paragraph and text, and still consider the aspects of writing such as organization, language use, vocabulary, mechanics, and its content.

Writing skill belongs to the most difficult skill because there are many factors that should be considered. The important factors that influence writing skill are vocabulary mastery and reading habit.

Vocabulary is the most important aspect that cannot be separated with language skill. Vocabulary is a list of the word known and used by the particular person. There are many languages in the world and each language has a different form to label something. For example to label a long curved fruit with a thick skin that is yellow in English are called by banana, meanwhile, in Indonesia are called by pisang. To master English languages skill especially writing, students have to master vocabulary too, because vocabulary is the aspect of writing skill. Vocabulary is related to word, form, and meaning. As stated by Thornbury (2002: 15), knowing a word involves knowing its form and its meaning. It is mean that if someone knows about a word, they have to understand about its form and its meaning.

The term mastery according to Hornby in Al Qahtani (2015: 26) is "complete knowledge or complete skill". But, Hiebert \& Kamil (2005: 2) state, vocabulary is not a developmental skill. Based on the definitions by the experts above, the writer concludes that vocabulary mastery is the complete knowledge of the form, meaning, and the use of a set of words which are used to express ideas.

The second aspect that influences vocabulary is reading habit. Sangkaeo in Busayo (2011: 3) states that reading habit refers to behaviors which express the likeness of reading of individual, types of reading and tastes of reading. Reading habit is an essential life skill. It not only increases our knowledge, but also builds maturity and character, sharpens our thinking, and widens our awareness in social economic political and environmental issues Pandian in $\mathrm{Al}$ Husaini (2013: 193). It means that reading habit is individual behaviors to read, and has a good effect on quality of a life skill.

To know students have a good reading habit or not, it can be analyzed by many aspects. Gaona and Gonzalez (2011) point out the five indicators to assess students reading habit are; (1) attitude toward reading; (2) reading frequency; (3) books read; (4) time spent; (5) motivation. Yusof (2010), find out that family factor affects students reading habit. A parent should be the role model to love to read. The other factor is the role of teacher. According to Edeole and Adejoke (2016), "reading habits for students develop in social contexts where they share their reading experience and interact with others such as family members, friends, and peers".

Based on the definitions above, the writer concludes that reading habit is an activity which expresses the likeness of people to read a text which has a purpose of gaining information by understanding 
the meaning of the text which is done repeatedly. If students have a good reading habit they will get the advantages in increasing their knowledge, sharpens their thinking and also build maturity and character. The role of family, teacher, and environment are important to motivate students' reading habit.

Based on the explanations above, the writer assumes that reading habit can affect the students' writing skill. Good reading habit can improve their writing skill. Good writing skill also can be affected by students' vocabulary mastery.

The hypothesis of the research can be formulated as follows:

1. There is a positive correlation between vocabulary mastery and writing skill

2. There is a positive correlation between reading habit and writing skill

3. There is a positive correlation between vocabulary mastery, reading habit simultaneously and writing skill.

\section{RESEARCH METHOD}

The research was conducted in one of junior high school in Karanganyar. In this research, the researcher used cluster random sampling. Cluster random sampling is the selection of groups, or cluster, of the subject rather than individuals, Wallen and Fraenkel (2012: 96). The following are the steps of selecting the class as the sample:

a. Listing the code of the name of the class

b. Writing down each code of class in a piece of rolled paper

c. Putting all pieces of paper in container

d. Shaking the container well

e. Taking the rolled papers

The chosen class was VIII D which is consisting of 26 students.
To analyze the problem of this research, the researcher used correlation research method. Singh (2007: 146), states correlation is one of the most widely used measures of association between two or more variables.

In this research, there are two kinds of variables, independent and dependent variables. The independent variables are vocabulary mastery $\left(X_{1}\right)$ and reading habit $\left(X_{2}\right)$.

The first step before conducting the test is doing try out. To test the validity and reliability of vocabulary mastery and reading habit instrument the researcher used validity and reliability test. Meanwhile, to test the writing skill instruction is readable or not, the researcher used readability test.

According to Wallen and Fraenkel (2012: 148), validity refers to the appropriateness, meaningfulness, correctness, and usefulness of the inferences a researcher makes. Meanwhile, reliability refers to the consistency of scores or answers from one administration of an instrument or another, and from one set of items to another, Fraenkel and Wallen (2012: 148).

After finding out the result of validity and reliability of the instrument, the researcher conducted the test to take the data. After that, to analyze the data, the researcher used normality test, linearity of regression test, significance of regression test, single correlation test, and multiple correlation test.

The statistical hypothesis can be formulated as follows:

1. First Hypothesis

a. $\mathrm{H}_{o}: r_{x 1 y}=0$ 
It means there is no correlation between students' vocabulary mastery $\left(\mathrm{X}_{1}\right)$ and writing skill $(\mathrm{Y})$.

b. $\mathrm{H}_{a}: r_{x 1 y}>0$

It means there is a positive correlation between students' vocabulary mastery $\left(\mathrm{X}_{1}\right)$ and writing skill (Y).

If null hypothesis $\left(\mathrm{H}_{o}\right)$ is rejected, there is a positive correlation between students' vocabulary mastery $\left(\mathrm{X}_{1}\right)$ and writing skill (Y).

2. Second Hypothesis

a. $\mathrm{H}_{o}: r_{x 2 y}=0$

It means there is no correlation between students' reading habit $\left(\mathrm{X}_{2}\right)$ and writing skill (Y).

b. $\mathrm{H}_{a}: r_{x 2 y}>0$

It means there is a positive correlation between students' students' reading habit $\left(\mathrm{X}_{2}\right)$ and writing skill (Y).

If null hypothesis $\left(\mathrm{H}_{o}\right)$ is rejected, there is a positive correlation between students' reading habit $\left(\mathrm{X}_{2}\right)$ and writing skill (Y).

3. Third Hypothesis

a. $\mathrm{H}_{o}: \mathrm{R}_{x_{1} x_{2} y}=0$

It means there is no correlation between students' vocabulary mastery $\left(\mathrm{X}_{1}\right)$ and reading habit $\left(\mathrm{X}_{2}\right)$ simultaneously and writing skill (Y).

b. $\mathrm{H}_{a}: \mathrm{R}_{x_{1} x_{2} y}>0$

It means there is a positive correlation between students' vocabulary mastery $\left(\mathrm{X}_{1}\right)$ and reading habit $\left(\mathrm{X}_{2}\right)$ simultaneously and writing skill (Y).

If null hypothesis $\left(\mathrm{H}_{o}\right)$ is rejected, it means that there is a positive correlation between students' vocabulary mastery $\left(\mathrm{X}_{1}\right)$ and reading habit $\left(\mathrm{X}_{2}\right)$ simultaneously and writing skill (Y).

\section{RESEARCH FINDINGS AND DISCUSSION}

The result of the validity and reliability test found that vocabulary mastery and reading habit instrument are valid and reliable. Moreover, the writing instruction is also readable.

Table 1.1. The Result of Normality Test.

\begin{tabular}{cccc}
\hline & $\left(\mathbf{X}_{\mathbf{1}}\right)$ & $\left(\mathbf{X}_{\mathbf{2}}\right)$ & $(\mathbf{Y})$ \\
\hline $\mathbf{N}$ & 26 & 26 & 26 \\
Mean & 53.6 & 70.4 & 69.5 \\
Standard Deviation & 11.7 & 11.2 & 6.6 \\
$\mathbf{L o}$ & 0.10 & 0.8 & 0.07 \\
$\mathbf{L t}$ & 0.17 & 0.17 & 0.17 \\
Status & Normal & Normal & Normal \\
\hline
\end{tabular}


Table 1.2. The Result of Linearity of Regression Test

\begin{tabular}{lccl}
\hline Variants & Value of Fo & Value of $\mathbf{F t}$ & Status \\
\hline $\boldsymbol{X}_{\mathbf{1}}$ and $\mathbf{Y}$ & 0.43 & 2.69 & Linear \\
$\boldsymbol{X}_{\mathbf{2}}$ and $\mathbf{Y}$ & 1.56 & 4.57 & Linear \\
\hline
\end{tabular}

Table 1.3. The Result of Significance of Regression Test

\begin{tabular}{cccc}
\hline Variants & Value of Fo & Value of Ft & Status \\
\hline $\boldsymbol{X}_{\mathbf{1}}$ and $\mathbf{Y}$ & 29.1 & 4.26 & Significant \\
$\boldsymbol{X}_{\mathbf{2}}$ and $\mathbf{Y}$ & 15.6 & 4.26 & Significant \\
\hline
\end{tabular}

Table 1.4. The Result of Multiple Linear Regression Test

\begin{tabular}{cccc}
\hline Variants & Value of Fo & Value of $\mathbf{F t}$ & Status \\
\hline $\boldsymbol{X}_{\mathbf{1}}, \boldsymbol{X}_{\mathbf{2}}$, and $\mathbf{Y}$ & 21.8 & 3.4 & Significant \\
\hline
\end{tabular}

After getting the validity, reliability, and readability of the instrument, the researcher conducted the test and analyzed the data by using normality test, linearity, of regression test and significance of regression test. The results show that the data are in normal, linear, and significant. After finding the result, the data are used in hypothesis testing. The hypothesis used single correlation to find out the correlation between (1) vocabulary mastery and writing skill; (2) reading habit to writing skill. Then, multiple correlations is used to determine the correlation between vocabulary mastery, reading habit, and writing.

The testing hypothesis show:

\section{First Hypothesis}

The null hypothesis $\left(H_{0}\right)$ is rejected and the alternative hypothesis $\left(H_{a}\right)$ is accepted. The result of the computation shows that the coefficient $r_{X 1 Y}$ between vocabulary mastery $\left(\mathrm{X}_{1}\right)$ and writing skill (Y) is 0.74. The conclusion is there is a positive correlation between vocabulary mastery $\left(\mathrm{X}_{1}\right)$ and writing skill $(\mathrm{Y})$.

A positive correlation between students' vocabulary mastery and writing skill shows that vocabulary is able to support writing skill. Because vocabulary is one factor of writing skill, so by mastering vocabulary, students will get a lot of vocabulary and finally, they can express something with the word they are got. Willis (2008: 80) states students will grow in a skill of verbal fluency, writing, and comprehension by mastering vocabulary. If students have a lack of vocabulary it will make they difficult to master writing skill. If students have rich vocabulary they get a high score in their writing.

Based on the explanation above, it can be concluded that vocabulary mastery has a relationship 
with writing skill. The improvement of vocabulary mastery will be followed by the improvement of writing skill. So, vocabulary mastery has a positive correlation and gives the positive contribution toward writing skill.

2. Second Hypothesis

The null hypothesis $\left(H_{0}\right)$ is rejected and the alternative hypothesis $\left(H_{a}\right)$ is accepted. The result of the computation shows that the coefficient $r_{X 2 Y}$ between reading habit $\left(\mathrm{X}_{2}\right)$ and writing skill (Y) is 0.63 . The conclusion is there is a positive correlation between reading habit $\left(\mathrm{X}_{2}\right)$ and writing skill $(\mathrm{Y})$.

To increase writing skill, students should improve their reading habit too. According to Krashen (2004: 37 ), "reading is the only way we become a good reader, develop a good writing style, an adequate vocabulary, advanced grammatical competence, and the only what we become good speller". Lack of vocabulary and bad grammatical competence constrains the students in creating writing essay. By reading habit they can develop their vocabulary and grammatical competence, so they can improve their writing skill too.

Based on the explanation above, it can be concluded that reading habit has a relationship with writing skill. The improvement of reading habit will be followed by the improvement of writing skill. So, reading habit has a positive correlation and gives the positive contribution toward writing skill.

3. Third Hypothesis

The null hypothesis $\left(H_{0}\right)$ is rejected and the alternative hypothesis $\left(H_{a}\right)$ is accepted. The value of the coefficient of multiple correlations (r) is 0.809 . It means that there is a positive correlation between vocabulary mastery $\left(\mathrm{X}_{1}\right)$ and reading habit $\left(\mathrm{X}_{2}\right)$ toward writing skill $(\mathrm{Y})$.

Vocabulary is one component of writing skill. To improve writing skill, students have to improve vocabulary too. Solati-Dehkodi and Salehi (2016: 152) state, vocabulary is one of the most essential features of writing. By learning vocabulary the writers will be helped how to spell the word in correct form, select the appropriate word to write something, and understand to use the word that suitable with its class.

Krashen (2004: 37) states reading is a way to develop a writing style, adequate vocabulary, and advanced grammatical competence. Therefore, Thahar in Wahyuni (2014: 22) states, high reading habits can help someone to improve his/her understanding of the development, writing organization, the choice of words, spelling, and grammar. It means the students can increase their reading habit to improve their writing skill because the more they read the more they learn. Reading habit helps the writers to improve not only the component of writing such as vocabulary, grammar, and organization but also the skill as summarizing, paraphrasing, interpreting, and synthesizing.

Based on the explanation above vocabulary mastery and reading habit give a positive contribution and automatically has a positive correlation to writing. 


\section{IMPLICATION}

Based on the result of the study, there is a positive correlation between vocabulary mastery, reading habit, and writing skill. The result of this study shows that reading habit and vocabulary mastery give the contribution to writing skill, it is $65.5 \%$. It implies that to improve writing skill cannot neglect vocabulary mastery and reading habit because vocabulary mastery and reading habit give positive contribution toward writing skill. However, we cannot ignore $34.5 \%$ of other factors which contribute writing skill.

Vocabulary mastery is an important factor for students to improve their writing skill. By mastering vocabulary they will easy to write words in correct spelling, chose the appropriate word to label something, and understand the usage of the word. Students who do not have knowledge about vocabulary, their writing maybe have much incorrect spelling, not appropriate diction, and wrong to use the word.

Besides mastering vocabulary, students also should have a high score in reading habit, because reading habit also gives a positive contribution to students writing skill. By often reading, students will get knowledge and information from the text. Reading habit also gives opportunities to the students to learn about grammar or construction of the words.

Below are many ways to increase students' writing skill:

1. The teacher should give the assignment that related to reading habit and writing skill, to encourage students' writing skill, for example, ask the students to read many English texts, list the difficult words, and develop that words into sentences.
2. The teacher should enrich the planned assignment by adding vocabulary tasks such as word listing, crossword games, matching items, spelling bee, or other kinds of vocabulary activities. Therefore, the students' vocabulary mastery can also improve.

3 . The teacher should give more attention to the students who get a low score in vocabulary mastery, reading habit, and writing skill, by asking the students to make groups that consist of at least one student with a high score in each variable. Then, they can learn and share about their difficulties in improving vocabulary mastery and reading habit to improve writing skill.

4. The teacher should motivate students to read and write frequently, for example; ask the students to write their opinion about the English text or book which interest to them; or summarize the English text or book that they have read.

Therefore, vocabulary mastery and reading habit are important to the students to increase their writing skill. In other words, students have to increase their vocabulary and reading habit to increase their writing skill.

\section{CONCLUSION AND SUGGESTION}

The result of this study show that (1) there is a positive correlation between vocabulary mastery and writing skill $\left(r_{X 1 Y}\right.$ $=0.74)$; (2) there is a positive correlation between reading habit and writing skill $\left(r_{X 2 Y}=0.63\right)$; (3) there is a positive correlation between vocabulary mastery, reading habit, and writing skill $\left(r_{X 1 X 2 Y}=\right.$ $0.809)$.

(1) The relative contribution is $64.79 \%$ while the effective contribution is $42.44 \%$. It indicates that increasing and 
decreasing students' writing skill is in line with vocabulary; (2) The relative contribution is $35.21 \%$ while the effective contribution is $23.06 \%$. It indicates that increasing and decreasing students' writing skill is in line with reading habit; (3) The contribution of vocabulary and reading habit to writing skill is $65.5 \%$. It means $65.5 \%$ of writing skill is determined by vocabulary and reading habit. It indicates that the increasing and decreasing of students' writing skill is in line with vocabulary mastery and reading habit.

Based on the result of the study, there is a positive correlation between reading habit, vocabulary mastery simultaneously toward writing skill. The coefficient determination is 0.655 , or it means $65.6 \%$ of writing skill is determined by vocabulary and reading habit. Therefore, $34.5 \%$ of writing skill is determined by other factors. The researcher expects that there will be other researchers who investigate other aspects relating to writing skill, and hopefully, this research can be used as a reference to their research that similar with this study.

\section{BIBLIOGRAPHY}

Al Husaini, Z.A.E. (2013). Knowledge, attitude, and practice of reading habit among female medical students, Taibah University. Journal of Taibah University Medical Science 8(3) page 192198.

Al Qahtani, Mofareh. (2015). The Importance of Vocabulary in Language Learning, and How to be Taught. International Journal of Teaching Education. Vol.III No.4.

Barkaoui, Khaled. (2007). Teaching Writing to Second Language
Learners: Insight from Theory and Research. TESL Reporter 40,1 pp 35-48.

Brown, H Douglas. (2001). Teaching by Principles: An Interactive Approach to Language Pedagogy. (second edition).

Busayo, IO. (2011). The School Library as a Foundational Step to Childrens' Effective Reading Habits. Library Philosophy and Practice.

Gaona, J.C.G \& Gonzalez, E.R.V. (2010). Relationship Between Reading Habits, University Library and Academic Performance in A Sample of Psychology Students. Revista de la Education Superior, Vol XL (1), No. 157

Hiebert, E.H \& Michael L. Kamil (2005). Teaching and Learning Vocabulary. London: Lawrence Erlbaum Associates Inc

Huy, NT. (2015). Problems Affecting Learning Writing Skill of Grade 11 at Thong Linh High School. Asian Journal of Educational Research. Vol 3, No. 2.

Krashen, Stephen D. (2004). The Power of Reading: Insight from the Research. Westport, Conn: Libraries Unlimited.

Patel, DR.M.E and Praven M Jain. (2008). English Language Teaching. Jaipur: Sunrise Publishers \& Distributors.

Richards, Jack C, and Willy A. Renandya. (2002). Methodology in Language Teaching. New York: Cambridge University Press.

Singh, Kultar. (2007). Quantitative Social Research Methods. New Delhi: SAGE Publications. 
Solati-Dehkordi. S.A and Hadi Salehi. (2016). Impact of Explicit Vocabulary Instruction on writing Achievement of UpperIntermediate EFL Learners. Canadian Center of Science and Education: International Education Studies, Vol. 9, No. 4

Thornbury, Scott. (2002). How to teach Vocabulary. Malaysia: Pearson Education Limited.

Ur, Penny. (2009). A Course in Language Teaching. UK: Cambridge University Press.

Wahyuni, Irna. (2014). The Effect Collaborative Writing and Reading Habits toward The Students' Writing of Recount text at The Eight Grade of MTs N
Kamang. Journal English Language Teaching (ELT). Vol.2, No.2.

Wallen, Norman E \& Jack R Fraenkel. (2012). How to Design and Evaluate Research in Education. 8ht Ed. USA: Mc Graw Hill.

Willis, Judy. (2008). Teaching the Brain to Read. USA: Association for Supervision and Curriculum Development.

Yusof, N.M. (2010). Influence of Family Factors on Reading Habits and Interest among Level 2 Pupils in National Primary Schools in Malaysia. ScienceDirect. Vol.5 No.1160-1165. 